\title{
4. DEFERÊNCIA JUDICIAL ÀS DECISÕES DO CADE E O EQUILÍBRIO ENTRE OS PODERES CONSTITUÍDOS
}

\section{Judicial deference to CADE's decisions and the balance between constituted powers}

Humberto Santos ${ }^{1}$

\section{RESUMO}

O objetivo do texto consiste em ressaltar a importância da deferência judicial para o equilíbrio dos poderes constituídos, sendo analisada a partir de pedidos revisionais que questionam decisões proferidas pelo Conselho Administrativo de Defesa Econômica - Cade. A discussão é conduzida tendo por ponto de partida precedente do Supremo Tribunal Federal (Recurso Extraordinário no 1.083.955DF), cujo teor sinaliza a favor dessa postura. Parte-se do pressuposto de que a expertise técnica confere condições à extração de sentido mais acurado na aplicação da norma antitruste, privilegiando uma abordagem de discussão do assunto pela prática de concretização do direito. A revisão judicial se justificaria, portanto, somente para correção de ilegalidades ou abusos evidentes, sem envolver um juízo revisional amplo substitutivo às decisões do Cade. Conclui-se favoravelmente à postura de deferência judicial como atitude institucional de um desejado equilíbrio no exercício entre os poderes constituídos.

Palavras-chave: Revisão judicial; Cade; Deferência; Expertise; Instituições.

\begin{abstract}
The purpose of the text is to emphasize the importance of judicial deference to the balance of constituted powers, being analyzed based on review's requests decided by Brazilian Administrative Antitrust Authority - CADE. The argumentation is conducted based on the analysis of a precedent issued by Brazilian Supreme Court (RE no 1.083.955-DF), which points in favor of this stance. It is assumed that technical expertise provides condition to give the better meaning of antitrust law, privileging an approach of the law through its practice. The judicial review would therefore be justified only to correct evident illegalities or abuses, but not as a broad review in substitution for CADE's decisions. It is concluded favorably to judicial deference as an outcome of a desired institutional balance between the constituted powers.
\end{abstract}

Keywords: Judicial review; CADE; Judicial deference; Expertise; Institutions.

1 Doutorando em Direito Comercial pela Universidade de São Paulo. Mestrado em Direito pelo CEUB. Pós-graduação lato sensu em Direito Econômico e Defesa da Concorrência pela FGV. Pós-graduação lato sensu em Regulação Econômica pelo CEFET/RJ. Bacharel em Direito pelo CEUB e Licenciatura em Ciências Sociais pela UnB. Professor de Direito do CEUB. Procurador Federal da AGU com atuação perante o Cade E-mail: humberto.santos@cade.gov.br 
Sumário: 1. O sentido do Direito expresso na prática. 2. O Recurso Extraordinário no 1.083.955-DF - e os limites da revisão judicial de decisões proferidas pelo Cade. 2.1 - O posicionamento do STF. 2.2 - A repartição e o equilíbrio no exercício dos poderes constituídos (art. 2o da CF/88). 2.3 - Capacidades institucionais e o papel revisional esperado do judiciário. 3. Conclusão. 4. Referências.

\section{INTRODUÇÃO}

O artigo se propõe a discutir a importância da deferência judicial diante de pedidos revisionais que questionam decisões proferidas pelo Conselho Administrativo de Defesa Econômica - CADE. Toma-se, por ponto de partida, o precedente do Supremo Tribunal Federal - STF, exarado no Recurso Extraordinário no 1.083.955-DF, cujo teor sinaliza a favor de uma postura de autocontenção do judiciário no julgamento de demandas judiciais com essas características.

Na estruturação do texto, propõe-se, inicialmente, um breve panorama contextual que realça como o sentido de aplicação do direito se dá por meio de sua prática, ganhando concretude por intermédio de um processo interpretativo, no qual o intérprete encarregado de aplicação da norma atribui sentido aos comandos normativos diante de situações específicas. Nesse processo, a expertise técnica mostra-se fundamental para permitir a extração de sentido que implemente a aplicação da norma de forma mais adequada, especialmente quando se está diante de estruturas normativas com preceitos abertos, como a legislação antitruste.

Além da expertise técnica, é preciso que o órgão encarregado de aplicação da norma detenha capacidade institucional para o bom exercício dessa atribuição. Esses temas, alguns mais explícitos outros menos, estão contidos no precedente exarado pela Suprema Corte e serão objeto de discussão em tópicos específicos.

Após retratar o iter processual do Recurso Extraordinário no 1.083.955-DF, ao final, contextualizado com o diálogo político que permitiu a atribuição dos arranjos institucionais do Cade, conclui-se favoravelmente à postura de deferência do judiciário como forma de se obter um desejado equilíbrio institucional no exercício dos poderes constituídos, sem que haja necessidade, para tanto, de vinculação à "chevron doctrine" norte-americana

\section{O SENTIDO DO DIREITO EXPRESSO NA PRÁTICA}

A compreensão sobre os atributos constitutivos do direito exige um olhar voltado para sua prática. O sentido atribuído às proposições jurídicas revela como o direito realmente se concretiza já que, como bem posto por Kelsen (2003, p. 126), no seu processo de aplicação, nunca se trata, efetivamente, de pura aplicação, havendo sempre espaço reservado à criação desse sentido pelo intérprete, o qual terá sua liberdade de criação limitada pela elasticidade dos termos definidos pelo ordenamento.

Essa particularidade do direito se mostra essencialmente valiosa para o antitruste e para as áreas de regulação econômica em geral. E isso ocorre porque, usualmente, nesses campos, as normas jurídicas se apresentam encerradas em "molduras", capazes de legitimar diversos sentidos 
de aplicação. Mais uma vez valendo-se do referencial explicativo de Kelsen (2009, p. 151), diante de normas assim consideradas, "sob a ótica do direito positivo, não existe critério pelo qual uma das dadas possibilidades de aplicação da norma possa ser preferida à outra."

Ao se analisar a estrutura normativa da legislação antitruste (seja na lei anterior - 8.884/94 ou na lei vigente - 12.529/11), constata-se a predominância de preceitos abertos, sujeitos a sentidos diversos de aplicação, passiveis de exprimir diferentes resultados no processo de aplicação do direito, aderente, portanto, à tipologia de moldura normativa, "dentro da qual são apresentadas várias possibilidades de execução, de modo que todo ato é conforme a norma, desde que esteja dentro dessa moldura, preenchendo-a de algum sentido possivel" (Kelsen, 2009, p. 150).

A complexidade e a mutabilidade das práticas dos mercados se apresentam como razões justificadoras para que a lei se apresente com preceitos assim tão elásticos. Espera-se que um órgão, mais bem capacitado que o parlamento e o judiciário, seja dotado de expertise técnica e poderes operacionais para bem desempenhar o papel de dissuadir e repreender as práticas lesivas à concorrência no país no tempo compativel com as dinâmicas dos mercados. Se, por um lado, a edição de uma lei com preceitos tão abertos, como a norma antitruste, traz certa insegurança em relação ao sentido que a autoridade antitruste a aplicará, por outro, espera-se que o resultado dessa escolha seja o melhor possível, capaz de conferir a extração máxima dos objetivos definidos pela norma.

A definição por esse arranjo político-institucional não afasta o conhecimento dessa matéria pelo judiciário. Num sentido sociológico, Bourdieu (2010, p.212) descreve o campo jurídico como sendo um local de concorrência pelo monopólio de dizer o direito, a ser exercido por agentes investidos de competência social e técnica para tanto, cujo fazer "consiste, essencialmente, na capacidade reconhecida de interpretar (de maneira mais ou menos livre autorizada) um corpus de textos que consagram a visão legítima, justa, do mundo social." Ao refletir sobre a práxis desse campo, o autor realça como o processo de interpretação e, portanto, de aplicação do direito se revela como sendo a "forma, por excelência, do poder simbólico de nomeação que cria as coisas nomeadas", atribuindo às decisões ("o veredicto do juiz") o caráter "mágico de dizer o que, na verdade, elas são."

Incorporando as contribuições desse olhar sociológico para compreensão de nossa prática e direcionando-as ao objeto de discussão, será infração à ordem econômica o que a comunidade jurídica entender como tal, o que, por certo, perpassará pela compreensão e discussão a ser travada por todos os agentes legitimados à interpretação do direito antitruste, tendo por locus privilegiado e preponderante a esfera administrativa, assim constituída e legitimada por vontade política do legislativo (cf. Lei no 12.529/11), pelo menos no que tange ao enforcement público não-penal.

Entretanto, o "ato mágico" performativo que o sentido de aplicação da lei antitruste terá depende, em última instância, da concordância do judiciário, caso essa seara venha a ser provocada a enfrentar o tema. E tudo isso deve, como a seguir se pretende aprofundar, por força do equilíbrio institucional esperado no exercício dos poderes constituídos, todos eles legitimados, em algum grau, a dizer o que de fato é o direito.

Para que, portanto, diante de normas tão elásticas, o processo de aplicação do direito não se desnature num "vale tudo" interpretativo, em que o limite extraível de sentido passe a residir somente na semântica dos termos e variável conforme a interpretação subjetiva de cada qual, mostra-se de fundamental importância a explicitação do respaldo técnico das decisões. 
É, essencialmente, essa expertise, aliada a um agir compativel com outros casos já decididos no mesmo sentido, que legitimará o processo decisório da autoridade antitruste e permitirá, ao final, contar com a chancela judicial nos pleitos revisionais.

Cabe destacar que essa forma de compreensão da prática jurídica é muito familiar aos países de filiação à common law. Apesar de Bustamante (2008) não vislumbrar diferenciação teórica na forma de o juiz decidir tanto na civil law quanto na common law, deve-se sublinhar que nos países da common law vigora com maior pujança o preceito "stare decisis et non quieta movere", o que costuma resultar num comportamento de se seguir o que já fora julgado, não importando se na esfera administrativa ou judicial. Na sintese de Schauer (2009, p. 37), "sob a doutrina do stare decisis, é esperado que a Corte decida questões da mesma forma que as decidiu no passado, mesmo que a composição da Corte tenha mudado ou mesmo que os membros tenham mudado de mentalidade. Tal como precedentes verticais, stare decisis - precedente horizontal - é sobre seguir decisões dos outros." (tradução livre).

Não é de se estranhar, portanto, que Bruno Drago (2015, p.326) reconheça nas leis concorrenciais "aquilo de mais próximo que os sistemas continentais poderiam ter com a common law."

Esse breve panorama auxilia a compreender a importância do precedente do Supremo Tribunal Federal - STF, exarado no julgamento do Recurso Extraordinário no 1.083.955-DF, o qual passa a ser discutido na sequência, especialmente por realçar o papel decisivo que a expertise técnica confere ao sentido de aplicação da norma. Além disso, ainda que o precedente não goze de efeito vinculante, mostra-se nítida sua vocação de parametrizar como o judiciário deve analisar pleitos revisionais oriundos de autoridades administrativas que detenham competência para aplicação de normas abertas de regulação de mercados em sentido amplo, já que o acórdão acabou sendo confirmado pelo plenário do STF, permitindo o escrutínio do caso por todos os ministros da Corte, após a interposição de embargos de divergência pelos recorrentes (AgR-ED-EDv-AgR, julgado em 13/05/2020).

Para além do propósito deste artigo, o precedente também suscita reflexões de outras magnitudes, como a conveniência de instituição de varas especializadas para o julgamento de causas antitrustes no âmbito da justiça federal ou mesmo incentivos à utilização de outros meios de solução de controvérsia, como a arbitragem, em razão de tecer considerações sobre dificuldades institucionais que o judiciário teria para exercer juízo revisional amplo de causas dessa natureza. Por evidente, o aprofundamento desses temas ensejaria trabalhos específicos, incabíveis no recorte ora realizado.

\section{RECURSO EXTRAORDINÁRIO N 1.083.955-DF - E OS LIMITES DA REVISÃO JUDICIAL DE DECISÕES PROFERIDAS PELO CADE}

O Recurso Extraordinário no 1.083.955-DF versou sobre discussão que, desde a origem, buscava anular ato decisório do Conselho Administrativo de Defesa Econômica - Cade - que, com fundamento no processo administrativo no 0800.024581/1994-77, havia condenado a recorrente e outros envolvidos por práticas colusivas, consistentes na criação de barreiras artificiais à entrada de outras empresas no mercado de distribuição de combustíveis no Distrito Federal.

Ao final do trâmite do processo administrativo, o Cade concluiu que os representados valeram-se de seu poder econômico para buscar eliminar a concorrência no mercado relevante consi- 
derado, impedindo a entrada de rede de hipermercado local (rede Carrefour) no ramo de revenda de combustiveis. No entendimento do Cade, os representados exerceram pressões em membros do executivo e do legislativo para que não fosse autorizada a entrada de concorrentes nesse mercado, bem como fosse editada lei impeditiva em tal sentido (resultando na Lei Complementar Distrital no 294/2000) preservando seus nichos de mercado, o que configuraria infração à ordem econômica, nos termos dos artigos 20, I, II e IV, e 21, II, IV, V e X, da Lei 8.884/1994, tendo sido imposta a penalidade de multa, cumulada com a inscrição no Cadastro Nacional de Defesa do Consumidor e publicação de anúncio de meia página em jornal de grande circulação com o extrato da decisão punitiva.

Além desse fato, na esfera administrativa, no mesmo julgamento, o Cade entendeu que restou caracterizada a prática de adoção de comportamento uniforme pelo sindicato da categoria (SINPETRO - Sindicato do comércio varejista de derivados de petróleo no DF) ao impedir que fosse comercializado óleo diesel aditivado pelos postos de revenda de combustivel na região, fato comprovado, entre outros documentos, por ata assinada pelos membros sindicalizados assumindo esse compromisso, o qual contava com cerca de $95 \%$ dos agentes de mercado à época filiados ao sindicato no mercado relevante considerado.

Em radical modificação do entendimento externado pelo Cade, o juízo da 17ą Vara Federal da Seção Judiciária do Distrito Federal entendeu que a conduta imputada aos autores consubstanciaria mero lobby, prática inapta a configurar infração à ordem econômica e, portanto, sob esse fundamento, deu provimento ao pedido de anulação da decisão condenatória.

Irresignado, o Cade levou a matéria ao conhecimento do Tribunal Regional Federal da 1a Região. No julgamento da apelação do órgão antitruste, a Corte decidiu pela restauração da decisão administrativa condenatória. Cabe destacar breve trecho do voto do relator que sintetizou a discussão travada no caso:

(...) Atribuir qualificação diversa a fatos incontroversos - no caso a atuação das autoras e de seu sindicato na repressão à entrada de novo distribuidor no mercado varejista de combustiveis com prejuízo à livre concorrência - é negar o juízo de valor que o legislador incumbiu a um órgão de composição plural e de conhecimentos técnicos sobre a matéria. Estivesse o juiz examinando a vulneração de qualquer outro requisito do ato (competência, finalidade, forma, objeto, motivação), certamente que admissivel o controle judicial. No caso concreto, entretanto, o que se viu foi a completa substituição de um juizo valorativo por outro.

A partir, portanto, desse acórdão é que a discussão jurídica foi levada aos tribunais superiores, não tendo os recorrentes logrado êxito no recurso especial também interposto perante o Superior Tribunal Justiça (RESP no 1436903 /DF). Junto ao STJ, o voto do Min. Herman Benjamim repreende severamente o que fora praticado pelo juízo sentenciante, qualificando de "aventura jurídica" a forma como se deu a mudança de entendimento substitutiva à proferida pelo Cade, tendo seu posicionamento sido acolhido por unanimidade pela 2a Turma do Tribunal. Seu voto destaca que:

A fundamentação produzida na sentença para anular a decisão administrativa foi de que a mera pressão e o lobby exercido perante as autoridades públicas não configuram infração à ordem econômica. Depreende-se que 
a análise perpetrada pelo juiz sobre o mérito do ato administrativo não foi jurídica, mas, pelo contrário, casuística, uma verdadeira aventura jurídica, pois não compreendeu os relevantes fatos e provas produzidos pelo CADE, onde ficou evidenciada a formação de Cartel entre as empresas e o cometimento de infração à ordem econômica. (grifos nossos)

Contra esse acórdão, os recorrentes se valeram de todos os recursos possiveis para tentar resgatar a conclusão revisional contida na sentença, tendo sido provocada até mesmo a manifestação da Corte Especial do STJ. Por ocasião do julgamento de agravo nos embargos de divergência, em voto de relatoria do Min. Og Fernandes, a Corte Especial do STJ assentou, ao que importa à discussão presente, que:

Como já dito na decisão, ora agravada, em ambos os julgados foi admitida a intervenção do Poder Judiciário e não há, em nenhum deles, a premissa de que a tese jurídica firmada foi a de não ingerência no mérito administrativo. Ao revés, no próprio aresto embargado, admite-se (item " 6 ", supra) que o Judiciário pode imiscuir-se "na análise do mérito administrativo, desde que seja analisado sob o seu aspecto jurídico, e para que sejam observados, além da legalidade em sentido amplo, também os princípios e mandamentos constitucionais". (grifos nossos).

Sem êxito perante o STJ, restou o reexame da matéria pela via jurisdicional junto ao STF.

\section{1 - O posicionamento do STF}

O precedente do STF suscita diversas reflexões. Ainda que alguns capítulos do acórdão merecessem discussões mais aprofundadas, não há como negar que o teor do julgado serve como importante balizador sobre a definição dos limites da revisão judicial de decisões proferidas pelo Cade. Das várias considerações trazidas pelo julgamento, as que servem mais diretamente ao propósito deste artigo versam sobre repartição e equilíbrio no exercício dos poderes constituídos (art. 2o da CF/88), assim como os critérios que legitimariam a modificação da aplicação da lei antitruste pelo judiciário. Esses dois temas passam a ser discutidos com maior pesar nas linhas que se seguem.

Atribuída a relatoria ao Ministro Luiz Fux, inicialmente o recurso foi monocraticamente denegado, tendo por fundamento o (i) entendimento de adequação do que fora decidido à jurisprudência do STF, assim como pela (ii) incidência da súmula 279 do Tribunal, a qual impede a revisão de contexto fático-probatório.

A partir da interposição de agravo interno, restou mais clara a explicitação dos fundamentos decisórios contidos no precedente. 0 acórdão restou fixado com uma extensa ementa, da qual se extrai alguns trechos:

1. A capacidade institucional na seara regulatória, a qual atrai controvérsias de natureza acentuadamente complexa, que demandam tratamento especializado e qualificado, revela a reduzida expertise do Judiciário para o controle jurisdicional das escolhas políticas e técnicas subjacentes à regulação econômica, bem como de seus efeitos sistêmicos. 
2. O dever de deferência do Judiciário às decisões técnicas adotadas por entidades reguladoras repousa na (i) falta de expertise e capacidade institucional de tribunais para decidir sobre intervenções regulatórias, que envolvem questões policêntricas e prognósticos especializados e (ii) possibilidade de a revisão judicial ensejar efeitos sistêmicos nocivos à coerência e dinâmica regulatória administrativa.

3. A natureza prospectiva e multipolar das questões regulatórias se diferencia das demandas comumente enfrentadas pelo Judiciário, mercê da própria lógica inerente ao processo judicial.

4. A Administração Pública ostenta maior capacidade para avaliar elementos fáticos e econômicos insitos à regulação. [...]

5. A intervenção judicial desproporcional no âmbito regulatório pode ensejar consequências negativas às iniciativas da Administração Pública. Em perspectiva pragmática, a invasão judicial ao mérito administrativo pode comprometer a unidade e coerência da política regulatória, desaguando em uma paralisia de efeitos sistêmicos acentuadamente negativos.

6. A expertise técnica e a capacidade institucional do CADE em questões de regulação econômica demanda uma postura deferente do Poder Judiciário ao mérito das decisões proferidas pela Autarquia. O controle jurisdicional deve cingir-se ao exame da legalidade ou abusividade dos atos administrativos, consoante a firme jurisprudência desta Suprema Corte. [...]

7. Os controles regulatórios, à luz do consequencialismo, são comumente dinâmicos e imprevisiveis. [...]

8. A atividade regulatória difere substancialmente da prática jurisdicional, porquanto: 'a regulação tende a usar meios de controle ex ante (preventivos), enquanto processos judiciais realizam o controle ex post (dissuasivos); (...) a regulação tende a utilizar especialistas (...) para projetar e implementar regras, enquanto os litígios judiciais são dominados por generalistas' [...]

9. In casu, o Conselho Administrativo de Defesa Econômica - Cade, após ampla análise do conjunto fático e probatório dos autos do processo administrativo, examinou circunstâncias fáticas e econômicas complexas, incluindo a materialidade das condutas, a definição do mercado relevante e o exame das consequências das condutas das agravantes no mercado analisado. No processo, a Autarquia concluiu que a conduta perpetrada pelas agravantes se enquadrava nas infrações à ordem econômica previstas nos artigos 20, I, II e IV, e 21, II, IV, V e X, da Lei 8.884/1994 (Lei Antitruste).

10. O Conselho Administrativo de Defesa Econômica - Cade detém competência legalmente outorgada para verificar se a conduta de agentes econômicos gera efetivo prejuízo à livre concorrência, em materialização das infrações previstas na Lei 8.884/1994 (Lei Antitruste). 
11. As sanções antitruste, aplicadas pelo Cade por força de ilicitude da conduta empresarial, dependem das consequências ou repercussões negativas no mercado analisado, sendo certo que a identificação de tais efeitos anticompetitivos reclama expertise, [...]

12. O Tribunal a quo reconheceu a regularidade do procedimento administrativo que impusera às recorrentes condenação por práticas previstas na Lei 8.884/1994 (Lei Antitruste), razão pela qual divergir do entendimento firmado no acórdão recorrido demandaria o reexame dos fatos e provas, o que não se revela cognoscivel em sede de recurso extraordinário, face ao óbice erigido pela Súmula 279 do STF.

13. Agravo regimental a que se NEGA PROVIMENTO.

Merecem ser destacados alguns aspectos sobre os limites da revisão judicial de decisões proferidas pelo Cade para os fins propostos a este artigo.

\section{2 - A repartição e o equilíbrio no exercício dos poderes constituídos (art. $2^{\circ} \mathrm{da}$ $\mathrm{CF} / 88$ )}

Uma leitura apressada da ementa do acórdão do STF poderia sugerir que a Suprema Corte blindou a decisão de mérito proferida pelo Cade da sindicabilidade judicial. Isso seria, contudo, uma conclusão equivocada.

O voto do Min. Luiz Fux esclarece que "o acórdão recorrido jamais afirmou a impossibilidade, sob qualquer aspecto, da revisão judicial das decisões do Cade, inclusive se abusivas ou ilegais." Dito de outro modo, o precedente inicia a análise da matéria reafirmando a jurisprudência consagrada que entende ser cabivel a revisão do mérito do que fora decidido pelo Cade, e não apenas os requisitos formais do ato administrativo (competência, finalidade, forma, motivo e objeto), mas desde que reste demonstrada a presença de abuso ou ilegalidade na decisão administrativa.

Para se evitar interpretações tautológicas, a presença do abuso ou ilegalidade na decisão administrativa deve ser compreendida num contexto de adequado exercício harmônico e independente dos poderes constituídos (art. 2o da CF/88), tal como se passa a discutir, afinal, qualquer ação revisional proposta contra decisões do Cade traz considerações sobre como o Poder Judiciário deve reexaminar decisões previamente analisadas por um órgão do Poder Executivo, de acordo com as leis aprovadas pelo Poder Legislativo.

E, conforme discutido no tópico inicial deste artigo, a aplicação do que é expresso pelo direito, e que, portanto, como fundamento último, permite-nos concluir se alguma decisão mostrar-se-ia ilegal ou abusiva, perpassa pelo sentido de aplicação da norma que fora atribuído pelo intérprete.

No precedente discutido, o que salta aos olhos é que para entender que a decisão condenatória do Cade havia sido ilegal, o juízo monocrático assim o fez substituindo seu juízo valorativo sobre os fatos - reputados como incontroversos - ao juízo conclusivo do Cade, mudando completamente o sentido de aplicação da lei antitruste. 
Não se deve desconsiderar que a matéria de fundo, envolvendo limites ao exercício legítimo do lobby, enseja muita discussão controversa, especialmente no nosso país, dada a inexistência de legislação específica regendo o tema. Isso, contudo, não transfere ao judiciário a primazia para decidir quando o exercício do lobby se desnatura em infração à ordem econômica, ainda mais quando esse entendimento se substitui ao da autoridade administrativa especializada na matéria, sem trazer considerações concorrenciais sobre os mercados que foram impactados pela prática.

E isso se deve porque a caracterização de uma infração à ordem econômica não está totalmente contida nos termos definidos pela legislação antitruste. Na estrutura dessa tipologia, Roberto Freitas Filho (2009, p.20) a refere como sendo uma "norma aberta", cujo "sentido descritivo da norma não está expresso a priori em seu texto, ou seja, é necessário que o aplicador venha a especificar os elementos que compõem a regra na ratio decidendi da questão."

Em trabalho clássico sobre a defesa da concorrência no Brasil, Paula Forgioni (2005, p.201) destaca a presença de mecanismos que funcionam como "válvulas de escape" na definição normativa das infrações à ordem econômica, conferindo ao texto legal instrumentos de flexibilização e adaptação à realidade mutável que caracteriza a dinâmica dos mercados. Dentre esses mecanismos, a autora enumera conceitos que são essenciais para a caracterização de uma infração à ordem econômica, como (i) a extensão da definição da regra da razão, isenções e autorizações antitruste, (ii) o conceito "elástico de mercado relevante" e (iii) "o jogo do interesse protegido" que se busca assegurar pela aplicação da norma.

Nesse processo de atribuição de sentido da aplicação da norma, cabe, portanto, ao intérprete, de certo modo, criá-lo a partir de uma construção argumentativa que confira sentido às proposições que embasam sua conclusão. Esse sentido assegura, em condições possiveis, o que Hesse (1983, p.43) chamou de "concretização da norma", processo interpretativo sempre vinculado a problemas concretos a serem resolvidos, os quais, por certo, dependem do histórico de prática e familiaridade com o tema.

Em trabalho recente sobre a força criadora de riquezas e desigualdades que o direito suscita, Katharina Pistor (2020, p. 156) realça como o processo de "interpretation of law is always an act of lawmaking; this lies in the nature of trying to make sense of words in light of the complex reality of facts to which the law is applied."

Essas visões convergem com a reclamção de François Ost (2007, p.122) por uma "teoria lúdica" para compreensão do direito, capaz de articular os diversos atributos que marcam a gênesis e o desenrolar de um "jogo de linguagem caracterizador do discurso jurídico", operado segundo regras próprias, que, ao final, traduzem a prática jurídica.

No racional de repartição de poderes, ao definir, portanto, como se dará o campo de jogo dos atores legitimados ao exercício democrático do poder, ao atribuir ao Cade o ofício judicante sobre quais práticas caracterizam infração à ordem econômica, o Poder Legislativo, por meio das Leis 8.884/94 e 12.529/11, outorgou a um órgão do Poder Exectivo a competência para sua definição. E assim o fez por acreditar que esse órgão, dotado de expertise técnica e dos instrumentos necessários para tanto, o faria da melhor forma possivel, numa escolha política de arranjos institucionais preferivel, inclusive, à decisão que seria proferida pelo Poder Judiciário. 
Para que haja alteração desse quadrante institucional harmônico de funcionamento entre os poderes constituídos, é preciso que se tenha a evidência de algum abuso ou ilegalidade. 0 que o precedente do STF busca assentar, portanto, é que as decisões do Cade são passíveis de revisão, assegurando-se, assim, o respeito à garantia constitucional de inafastabilidade de apreciação judicial de qualquer lesão ou ameaça a direito (5ํ, XXXV da CF/88), mas que essa garantia não importa numa pretensão a um novo julgamento amplo e substitutivo ao que fora realizado na esfera administrativa, especialmente por faltar ao judiciário expertise e capacidades institucionais para tanto.

Daí se mostrar coerente, portanto, a postura de deferência que se espera que o judiciário tenha em relação às decisões proferidas pelo Cade, pois, ao julgar ações que pedem a anulação ou modificação dessas decisões, cabe ao judiciário rever, ou seja, reavaliar como foi decidida a questão posta e não propriamente se substituir ao que foi decidido pelo órgão administrativo especializado na matéria, sendo despropositado um novo julgamento de mérito a partir de uma tabula rasa, o que seria tido como um desrespeito às regras do jogo.

A rigor, a função judicante atribuída aos órgãos de defesa da concorrência faz com que eles ajam de forma similar ao judiciário, com atributos reativos e eventuais, num exercício tipicamente adjudicatório e não normativo. A qualificação regulatória que poderia ser conferida às decisões do Cade no exercício dessa competência só poderia ser tomada numa dimensão bem ampla, no sentido de que, a partir dos precedentes do Cade, a sociedade compreende como se dá, na prática, a implementação da política pública de defesa da concorrência no país, o que a aproximaria da noção comumente utilizada pelo direito econômico (cf. Aragão, 2005, p. 35), a qual também assim enxerga o papel desempenhado pelas decisões do judiciário em geral.

Levar em conta a caracterização da função adjudicatória praticada pelo Cade não desprestigia, contudo, a analogia que o precedente do STF faz com as funções regulatórias em sentido estrito, pois, tal como discorrido no tópico inicial deste artigo, o preenchimento do sentido aplicativo dos preceitos abertos da lei antitruste continua a exigir expertise na matéria, assim como outros instrumentos institucionais que não estão disponibilizados ao judiciário em geral. Ademais, como bem destacam Cristel Koop e Martin Lodge (2015, p.5), regulação é um conceito multifacetário, sendo tormentoso atribuir-lhe um sentido univoco, especialmente quando se verifica como o termo é utilizado na prática do direito.

No fundo, o que a rigor importa saber é como se deu a explicitação de sentido atribuída aos fatos e aos comandos abstratamente previstos na norma (art. 36 da Lei no 12.529/11) por quem resta legitimado a fazê-lo, o que torna absolutamente irrelevante a discussão adminitrativista, puramente teórica, que busca dissociar atos discricionários de atos vinculados. Não há que se falar em juízo de conveniência ou oportunidade em julgamentos sobre o que caracteriza infração à ordem econômica. Não faz sentido a aplicação desses conceitos diante de um juízo tipicamente adjudicatório. Também não se pode afirmar que estaríamos diante de atos vinculados, dada a amplitude conferida pela moldura normativa. Preferivel, por certo, é centrar-se na compreensão da práxis do direito que, como bem expressa Tercio Ferraz Junior (2014, p.48), põe a "decidibilidade como problema central da ciência do direito."

E, para o bom exercício desse mister, é necessário, por óbvio, que existam meios institucionais disponiveis para bem decidir. 


\section{3 - Capacidades institucionais e o papel revisional esperado do judiciário}

Num dos trechos mais enfáticos do precedente do STF sob exame, o Min. Luiz Fux destaca:

Os principais argumentos que fundamentam o dever de deferência do Judiciário às decisões técnicas adotadas por órgãos reguladores repousam na (i) falta de expertise e capacidade institucional de tribunais para decidir sobre intervenções regulatórias, que envolvem questões policêntricas e prognósticos de natureza técnica e (ii) na possibilidade de a revisão judicial ensejar efeitos sistêmicos nocivos à coerência e dinâmica regulatória administrativa.

A falta de expertise e de capacidade institucional ampla dos tribunais, assim como a possibilidade de ensejar efeitos indesejados na ampla revisão judicial do que fora decidido pelo Cade, constituem argumentos centrais, realçados pelo relator, para justificar a importância da deferência judicial.

As discussões sobre capacidades institucionais traduzem uma agenda rica de pesquisa multidisciplinar, mas que usualmente "não aprofundam discussões jurídicas", como destaca Diogo Coutinho (2017, p.586). A decisão do STF também não aprofunda essa discussão, talvez por não ser o veículo mais apropriado para isso, já que voltada para resolver uma contenda específica, sem com isso desprestigiar a vocação objetiva que o recurso extraordinário possui na nossa sistemática processual (art. 102, §3o da CF-88). Mas o precedente da Suprema Corte tem o mérito de realçar alguns aspectos que sinalizam a falta de capacidade institucional do judiciário para emitir juízos de mérito substitutivos aos do Cade, permitindo-nos explorar, inicialmente, se, de fato, existe esse déficit e, a partir daí, refletir sobre quais instrumentos formais e informais se mostrariam necessários para alteração desse quadro, acompanhado da constante ponderação se essa alternativa de implementação de novos arranjos institucionais seria a mais desejada para a sociedade em geral.

O enfrentamento de uma tema dessa envergardura exigiria um denso estudo empírico sobre as condições estruturais e de avaliação das práticas de funcionamento do judiciário brasileiro, especialmente da justiça federal por conta da presença do CADE nesses litígios (art. 109, I da CF-88).

Além disso, antes de se avançar no propósito de qualquer modificação das condições hoje existentes, seria necessário inicialmente nos convecermos, enquanto sociedade, que valeria a pena incorrermos nos custos (financeiros e culturais) que as mudanças ensejariam. Esse tradeoff é complexo, sendo tormentoso identificar e quantificar todas as variáveis envolvidas e, por razões óbvias, não esgotaria aqui. Tulio Coelho (2015, p. 138), por exemplo, expressa percepção favorável da advocacia privada sobre o papel revisional realizado pelo judiciário contra as decisões do CADE e acredita que os magistrados se tornarão mais familizariados com o antitruste com o simples passar do tempo.

No seminário "Os desafios da judicialização da defesa da concorrência, da regulação e do comércio internacional", ocorrido nos dias 12 e 13 de novembro de 2015, em Brasília, sob a coordenação do Ministro Ricardo Cueva, discutiu-se, dentre outros temas, a conveniência de criação de varas especializadas para o julgamento de matérias antitruste e de comércio internacional no âmbito da justiça federal ou até mesmo a atribuição de competência originária para julgamento dessas matérias diretamente aos tribunais regionais federais. Ao final do evento, concluiu-se pela aprovação 
de "uma moção para encaminhamento ao Conselho da Justiça Federal de proposta de estudo para a criação e instalação de varas especializadas da Justiça Federal, em todas as capitais do País, em direito da concorrência e comércio internacional, mesmo que se faça no modelo de especialização sem exclusividade" (CJF, 2017, p. 9), tendo por consenso o déficit de especialização do judiciário para tratativa desses temas.

Trata-se, como se vê, de um assunto que vem sendo discutido pela comunidade jurídica. $\mathrm{Na}$ falta dos estudos empíricos mencionados acima, numa abordagem mais pragmática, poder-se-ia cogitar num exercício especulativo, de caráter comparativo, consistente em avaliar se o judiciário deteria familiriadade e instrumentos preferiveis aos do Cade para lidar com a matéria de defesa da concorrência, capazes de justificar um juízo revisional amplo.

Esse tipo de reflexão mostra-se especialmente relevante se levarmos em consideração as disposições normativas acrescidas à Lei de Introdução ao Direito Brasileiro - LIND (Decreto-Lei no 4.657/42), as quais passam a exigir textualmente a necessidade de motivação "das consequências práticas da decisão" (art. 20, caput) em qualquer decisão judicial que decida de forma diversa ao que fora inicialmente julgado, devendo a motivação, inclusive, abranger as "possíveis alternativas" (parágrafo único do art. 20) à solução eleita.

Como, em regra, os pedidos revisionais contra as decisões do Cade buscam anular os processos administrativos condenatórios, num caso de exercício amplo desse escrutínio, a boa aplicação do art. 20, combinada com o art. 21, ambos da LINDB, também exigiria que a sentença motivasse "de modo expresso as consequências jurídicas e administrativas" provenientes da decisão de anulação ou revisão, visto que, por certo, tal juízo representaria uma substituição de entendimento daquele inicialmente externado pelo órgão administrativo, devendo minimamente endereçar as preocupações de tutela da concorrência que provocaram a decisão administrativa originária.

Em alguma medida, os defensores do juízo revisional amplo acreditam que o judiciário teria condições de bem fazê-lo e que, de certo modo, as decisões provenientes desse exercício seriam mais acertadas que as decisões proferidas orginalmente pelo Cade. Essa crença, contudo, não parece ser a mais crivel, sem que esse juízo signifique qualquer desprestígio ao poder judiciário.

As reflexões que Isaiah Berlin (2002, p.447-505) suscita sobre as formas de pensar a partir das diversas habilidades que a raposa possui em contraste com o único conhecimento detido pelo ouriço compõem um instigante pano de fundo para alimentar esse exercício investigativo. Talvez, nossos juízes, de formação mais generalista, detenham um amplo conhecimento sobre diversas áreas do direito, o que thes permitem uma visão sistêmica privilegiada sobre o ordenamento como um todo, tendo, pois, atributos típicos da raposa. Já o Cade talvez se assemelhe mais ao ouriço, conhecendo bem apenas o antitruste, e se vale desse conhecimento como sua zona de proteção, o que também pode vir a ser o traço caracterizador das agências reguladoras setoriais em seus campos próprios de especialização. "Pluralista ou monista", seja como for, Isaiah Berlin ressalva que o mérito dessa distinção não reside em atribuir uma forma preferivel de sistemas de crenças detido por cada um, mas sim em realçar as diferentes formas de pensar e de compreender que esses tipos encerram para lidar com as situações da vida (2002, p.448).

Comecemos a análise, portanto, pelos instrumentos institucionais. A partir da discussão dos meios procedimentais, podemos cogitar considerações sobre a familiaridade que o judiciário e o 
Cade possuem com a matéria, o que sustentará a elaboração de juízos comparativos entre ambos.

De início, cabe destacar a ampla instrução probatória que é realizada nos processos administrativos julgados pelo Cade. Conduzida por servidores especialistas na matéria, não raras vezes, a instrução é beneficiada por troca de informações, compartilhamento de percepções e documentos com outras autoridades de defesa da concorrência ao redor do mundo, dado o caráter transfronteiriço de incontáveis condutas no mundo globalizado, as quais envolvem ações praticadas no estrangeiro com efeitos no mercado nacional, como os cartéis internacionais.

Aliado a isso, seja durante a instrução do processo administrativo ou mesmo antes de julgá- los, pode o Cade se valer da celebração de acordos com os envolvidos na apuração das condutas, seja por meio de termos de compromisso de cessação (TCC) ou acordos de leniência, buscando pôr termo a discussões jurídicas sobre determinados aspectos controvertidos da política de defesa da concorrência, extrair informações e provas sobre outras eventuais infrações desconhecidas (leniência plus) ou até mesmo para reforçar o acervo probatório contra determinados agentes, concedendo-se o beneficio de extinção do processo investigativo em relação àqueles que cooperarem com a instrução, livrando-os de eventual punição sob o compromisso assumido de cessação imediata das condutas investigadas.

Para ilustrar a importância desses instrumentos, de 2003 a 2020, o CADE celebrou 101 acordos de leniência, com 29 termos aditivos a esses contratos e 23 pedidos de leniência plus. De 2015 a 2020, foram celebrados 297 TCCs, com a impressionante quantia de $\mathrm{R} \$ 3.754 .165 .334,31$ de contribuição pecuniária fixada em favor do Fundo de Defesa de Direitos Difusos - FDD (Cade em números). Além da obtenção de meios de provas contra outros acusados, o cumprimento desses acordos encerra a discussão sobre eventual cometimento da infração, o que se traduz em celeridade na resolução da contenda e certeza sobre o que restou estabelecido nos acordos, atributos fundamentais para a boa aplicação da política de defesa da concorrência.

Além disso, na instrução e julgamento dos processos punitivos, as informações obtidas ao longo do curso dos processos administrativos, mesmo que não resultem em punição dos envolvidos, permitem ao corpo técnico do Cade aperfeiçoar paulatinamente o exercício de suas atribuições, já que é pelo fazer cotidiano e pela proximidade com o trato das matérias que se adquire cada vez mais conhecimento sobre a dinâmica, o comportamento dos atores e a estrutura de cada mercado, aprimorando o exercício de todas as competências do órgão, inclusive as preventivas no controle de concentração e as relacionadas à advocacy em setores regulados.

Esse caminho lento e constante de aperfeiçoamento institucional é ambivalente. É também pelo exercício cotidiano de suas outras competências que o Cade aprimora seu escrutínio na instrução e julgamento dos processos punitivos, o que parece reforçar o acerto do precedente do STF ao assinalar que "a Administração Pública ostenta maior capacidade para avaliar elementos fáticos e econômicos próprios à regulação." A delimitação do conceito de mercado relevante nos processos punitivos, por exemplo, usualmente é beneficiada pelas informações obtidas na instrução dos atos de concentração envolvendo os mesmos mercados, pois nessa instrução específica há melhores condições e incentivos para que os agentes econômicos municiem o Cade com as informações mais fidedignas sobre aspectos material e geográfico que caracterizam a delimitação desse importante conceito analítico quando não se discute o caráter ilícito da conduta e se tem assegurado o sigilo 
legal das informações compartilhadas.

Não se deve desprezar que é pelo fazer cotidiano, sistemático, repetitivo e técnico que se mostra possivel lidar com a assimetria de informação que caracteriza o abismo existente entre a burocracia estatal e o dia a dia dos agentes econômicos em cada mercado, permitindo-se, com o passar do tempo, a extração do reforço legitimatório do agir institucional do órgão, respaldado pelo aprimoramento técnico das instruções e das decisões exaradas pelo órgão, no melhor sentido weberiano que caracterizaria o exercício racional desse tipo de poder (cf. WEBER, 2009, p. 144).

A tecnicidade das decisões do Cade também se revela no juízo valorativo sobre o acervo probatório colhido. Não raras vezes, dada a complexidade que envolve as práticas caracterizadoras de infrações à ordem econômica, o juízo que lastreia uma condenação administrativa depende da avaliação de indícios e provas indiretas, os quais necessitam a complementação de teorias econômicas a fim de explicitar a racionalidade econômica das condutas e o impacto que elas podem provocar no bom funcionamento dos mercados. Uma leitura mais cuidadosa do art. 36 da Lei no 12.529/11 revela a elasticidade da tipologia definidora das infrações, a qual exige familiaridade com a matéria para adequada extração de seu conteúdo.

Um detalhe ilustrativo do que ora se cogita é que o caso que originou o precedente do STF em análise é proveniente de uma discussão envolvendo o mercado de revenda de combustíveis, um dos segmentos que mais ocupa a pauta histórica de julgamentos do Cade, não se podendo cogitar em análise eventual. Curiosamente, foi justamente nesse mercado, também no Distrito Federal, que o Cade se valeu de uma das medidas interventivas mais drásticas até hoje praticadas, consistente na nomeação de um interventor para gerenciar a rede de postos do agente que detinha o maior share na região como forma de tentar extirpar o cartel estrutural que insistia em se manter no mercado relevante da capital. Tal determinação se deu num dos desdobramentos da "operação Dubai", deflagrada em conjunto com o Ministério Público do Distrito Federal e Territórios e a Polícia Federal (Cade, Inquérito Administrativo no 08012.008859/2009-86).

Ao final da instrução do referido inquérito, a rede CASCOL, também envolvida no caso que originou o precedente do STF em análise, ${ }^{2}$ acabou firmando voluntariamente um TCC com o Cade, com obrigação de recolhimento de mais de noventa milhões de reais em favor do FDD, sem levar essa discussão ao judiciário.

Ainda que o TCC não envolva o reconhecimento de culpa, seria muito ingênuo admitir que uma empresa se comprometeria a desembolsar tamanha quantia se estivesse $100 \%$ segura sobre a licitude de suas práticas investigadas. Ademais, nos termos da subcláusula 2.1 do TCC firmado, os signatários do acordo expressamente reconheceram participação no cartel, assumiram o envolvimento em algumas práticas investigadas pelo Cade e comprometeram-se a cessá-las imediatamente (Cade, Processo Administrativo no 08700.004602/2016-26).

É de se perquirir, portanto, se o judiciário dispõe realmente das mesmas capacidades institucionais para permitir amplos juízos substitutivos aos julgamentos realizados pelo Cade. Ao que tudo indica, assiste razão à Suprema Corte ao chamar atenção sobre o risco que a intervenção judicial

2 Antes referida como Rede GASOL, o Processo Administrativo no 0800.024581/1994-77 também abrangeu a Rede de Postos Igrejinha e o Sindicato dos postos revendedores na região, o SINPETRO/DF. 
desproporcional pode ensejar, podendo comprometer a "unidade e coerência da política regulatória, desaguando em uma paralisia de efeitos sistêmicos acentuadamente negativos."

Por fim, o reforço da postura deferente esperada pelo judiciário também perpassa pela constatação de características assemelhadas que o processo administrativo junto ao Cade possui em relação ao processo civil no que tange à oportunização ao contraditório e à ampla defesa, contando, inclusive, com a participação do Ministério Público Federal para proteção dos interesses difusos envolvidos na discussão da matéria (art. 20 da Lei no 12.529/11). Vale relembrar que o Código de Processo Civil se aplica subsidiariamente aos processos em trâmite no Cade, por disposição expressa do art. 115 da Lei no 12.529/2011.

Muitas perguntas derivam das considerações aqui tecidas e podem alimentar outras investigações. Não se tem a pretensão de esgotá-las. Mas, com fundamento no estado da arte que se tem hoje, seja na orquestração harmônica dos poderes constituídos, seja nas disposições vigentes da LINDB, o que se pode extrair do precedente do STF é que cabe ao judiciário rever o que fora praticado pelo CADE, e, nesse mister, corrigir eventuais desvios que o órgão tenha incorrido, especialmente em garantias reservadas ao devido processo legal, já que estamos diante de um arranjo institucional relativamente (i) novo - a Lei no 12.529/11 entrou em vigência em 29.05 .12 - e (ii) desafiador, ao atribuir ao mesmo órgão as competências para instruir e julgar os processos.

Não obstante haja a previsão de mecanismos que procurem blindar a Superintendência-Geral da ingerência de um poder hierárquico típico a ser exercido pelo Tribunal Administrativo, fato é que esse arranjo pode ensejar alguns desvios que não se mostrariam os mais desejados numa perspectiva deontológica sobre o agir procedimental esperado do Poder Público diante de fatos de natureza acusatória.

No equilíbrio institucional de atuação dos poderes constituídos, a revisão judicial sobre o agir procedimental do Cade consistiria num tema rico de contribuição do olhar privilegiado e democrático que o histórico institucional do judiciário possui no respeito às garantias constitucionais dos acusados em geral, levando em conta os mais diversos tipos de processos submetidos ao seu crivo, seja endossando os acertos ou corrigindo eventuais falhas verificadas na práxis do Cade, valendo-se, para tanto, da visão pluralista de raposa, referida por Isaiah Berlin (2002, p.447-505), na compreensão do tema.

Não obstante, cabe mencionar que o histórico de confirmação das decisões do Cade perante o judiciário indica que o órgão também tem observado as boas práticas nessa seara, o que retira qualquer atributo preocupante quanto a esse aspecto. Segundo Paulo Furquim, considerados apenas os casos com trânsito em julgado, "em $83 \%$ dos casos em que houve julgamento de mérito, a decisão administrativa foi mantida." (CJF, 2017, p. 26).

Não faria sentido, portanto, cogitar em julgamentos substitutivos ao já realizados pela autoridade administrativa, visto que essa última goza de melhores condições de escrutínio na extração do sentido aplicativo da lei antitruste.

Ainda que boa parte das considerações aqui tecidas tenha versado sobre discussões envolvendo o exercício da competência repressiva de sancionar condutas anticompetitivas, esse mesmo racional também se aplicaria às demais competências exercidas pelo órgão administrativo. 0 recorte 
mais restritivo de análise se deu apenas para se manter fiel ao tema propriamente discutido no precedente do STF, e sua extensão, para abranger as outras competências do órgão, não desvirtuaria a essência dos fundamentos ora debatidos em favor da deferência judicial.

\section{CONCLUSÃO}

Bem compreendida a delimitação dos campos de exercício de cada poder, entende-se que a garantia constitucional de inafastabilidade de apreciação judicial diante de lesão ou ameaça a direito restaria preservada, e, mediante uma postura de autocontenção do judiciário em relação às discussões meritórias, toda vez que não restasse evidenciada qualquer ilegalidade ou abuso de poder no agir decisório pelo Cade, a sentença judicial deveria privilegiar a manutenção do que fora decidido na esfera administrativa.

Esse agir, decorrente de estrita observância ao precedente do STF, contribuiria em prol de uma cultura de respeito e credibilidade das instituições num médio e longo prazo, visto que a estabilidade do sentido de aplicação da norma antitruste e sua predicabilidade à sociedade em geral, sinalizando em qual sentido deve se dar a aplicação da lei aos casos semelhantes, perpassa pela manutenção dos julgados da autoridade de defesa da concorrência no país pelo judiciário.

O prestígio das decisões do Cade, assim como de outros órgãos que exercem funções assemelhadas na ordenação dos mercados, notadamente as agências reguladoras, demanda, portanto, uma atividade tipicamente de controle a ser exercida pelo judiciário, centrando-se, em essência, na análise dos requisitos formais, bem como numa releitura da fundamentação ou motivação decisória, já que estamos diante de atos que gozam de presunção de juridicidade e, inexistente qualquer ilegalidade ou abuso, a sentença deveria resultar na confirmação do que fora concluído pela autoridade administrativa como forma de prestigiar o conhecimento técnico detido por esses órgãos, o que, para sociedade, propiciaria a almejada segurança jurídica, aqui compreendida como justa expectativa de que a lei antitruste signifique o que os órgãos especializados assim entendem. Vários outros efeitos irradiariam dessa cultura, como, por exemplo, o incentivo para que todos os interessados busquem esgotar os esforços e argumentos necessários para o bom julgamento da questão perante a esfera administrativa, privilegiando essa seara de discussão.

Nessa toada, entende-se que restariam preservados os objetivos políticos que motivaram a criação desses órgãos em prol de toda sociedade brasileira. Floriano Marques (2002, p. 84) destaca que esses órgãos representam “instrumentos jurídicos aptos à nova regulação estatal”, sendo caracterizados como:

entes administrativos dotados de autonomia e independência, que assumem, em nome do poder político, a função de regular um dado segmento da atividade econômica ou um dado conjunto de interesses metaindividuais. São dotados de grande especialidade, pois se prestam a atuar num subsistema jurídico (conjunto de regras, normas, princípios, finalidades e pressupostos adstritos a um dado setor da vida humana). (grifos nossos)

Se é bem verdade que o Cade possui um histórico mais longínquo, remontando desde a edição da Lei no 4.137/62, o órgão só ganha relevância institucional a partir da abertura econômica do 
país, iniciada a partir dos idos de 1990. Primeiramente, com a Lei oㅡ 8.158/91, mas verdadeiramente revolucionária com a Lei no 8.884/94, a partir dos arranjos institucionais que reforçaram sua autonomia decisória, inicialmente transformando-o numa autarquia, descentralizando, assim, o poder decisório da administração central para esse novo ente, agora dotado de personalidade jurídica própria, com competência exclusiva para julgar as infrações à ordem econômica no âmbito administrativo.

Além disso, a Lei no 8.884/94 dispôs sobre a qualificação objetiva para exercício do cargo de conselheiro do Cade (notório saber jurídico ou econômico, além da reputação ilibada), limitando a discricionariedade na indicação de autoridades para exercício no órgão, as quais, também, passariam a ter que contar com a chancela prévia do Senado Federal para restarem nomeadas pelo Chefe do Executivo, outro traço da concordância política exigida entre os poderes constituídos para o bom funcionamento do órgão.

E, por fim, a legislação ainda previu mandato para seus dirigentes e dispositivos expressos que realçavam a ausência de subordinação à pasta ministerial ou mesmo ao Presidente da República sobre o teor decisório das matérias tratadas pela lei, tudo como forma de conferir o melhor arranjo institucional possivel para que o processo de tomada de decisão se desse com embasamentos técnicos, minimizando interferências políticas ou pressões externas, com vedação expressa à exoneração ad nutum dessas autoridades. Na visão de Vinícius Marques (2015, p.21), ex-Presidente do Cade, esses arranjos, aliados a determinadas práticas verificadas, fez com o Brasil apostasse "no método de construção de práticas mais adequadas - better practices - sem enveredar pela importação acrítica das chamadas best practices."

Mas o fato é que a assimilação desses novos arranjos exige tempo para que a comunidade jurídica se familiarize com essas disposições e, não raras vezes, vozes dissonantes recolocam em discussão a conveniência política de tais regras institucionais que, tal como previsto originariamente pela Lei no 8.884/94, dispunham que as decisões da então Secretaria de Direito Econômico não ensejariam recurso para o seu superior hierárquico (art. 41) e que as decisões do Cade não comportariam revisão em sede administrativa (art. 50). Vale recordar que esses comandos da Lei no 8.884/94 traziam disposições diametralmente opostas ao que antes estabelecia a Lei no 8.158/91 que, por meio de seu art. 21, admitia a possibilidade de interposição de "recursos, voluntários ou de ofício, dirigidos ao Ministro da Justiça, das decisões administrativas de defesa da concorrência." Num intervalo muito curto, portanto, em pouco mais de três anos, mudou-se completamente o tratamento institucional em relação ao tema.

Ilustra o registro dessa disputa a impetração de mandado de segurança, pelo Ministério Público Federal, perante o ST, questionando decisão do Ministro da Justiça que havia não conhecido de recurso hierárquico apresentado pelo parquet contra decisão proferida pelo Cade, a teor do que dispunha o art. 50 da Lei no 8.884/94 então vigente. Em voto simples e cirúrgico, no julgamento do MS no 10.138/DF, a Ministra Eliana Calmon julgou o MPF carecedor de ação por falta de interesse juridicamente protegido, "traduzido este na necessidade e adequabilidade da medida processual intentada, diante dos precisos termos da legislação especial." O voto foi confirmado por unanimidade pela 1a Seção do STJ, em acórdão publicado em 28/11/2005.

Essa decisão do STJ foi recentemente confirmada pelo STF que, ao analisar o recurso ordinário interposto pelo MPF, denegou provimento ao apelo (RMS 25.874 - Rel. Min. Marco Aurélio, 1a 
Turma, julgado em sessão virtual, nos dias 12.3.2021 a 19.3.2021).

A Lei no 12.529/11 reforça a lógica institucional estabelecida pela Lei no 8.884/94 e estende a proteção do mandato a outras autoridades do Cade, sendo esse mesmo contexto também verificado nas discussões que acompanharam a aprovação do novo marco regulatório das agências reguladoras no país (Lei no 13.848/19) e que, mais recentemente, conferiram autonomia funcional ao Banco Central por meio da Lei Complementar no 179/21.

Vê-se, pois, que não é preciso enveredar em discussões que busquem importar teorias estrangeiras para respaldar a deferência judicial às decisões proferidas pelo Cade, como a incorporação do contexto norte-americano que permitiu o surgimento da "Chevron Doctrine." A "imigração de ideais", como salienta Bourdieu (2010, p.7), "raramente se faz sem dano", pois "separa as produções culturais do seu sistema de referências teóricas em relação às quais as ideias se definiram, consciente ou inconscientemente."

É preciso apenas, como ora aqui se buscou argumentar, bem delimitar o campo de exercício dos poderes legitimamente constituídos pelas leis da República em prol da sociedade brasileira, o que Montesquieu (1758, p. 116), em tom premonitório, já assinalava que ocorreria pelo "movimento necessário das coisas" que forçaria os poderes a caminhar de concerto ("mais, comme par le mouvement nécessaire des choses, elle sont contraintes d'aller, el les seront forcées d'aller de concert").

Ainda que a tripartição de poderes concebida por Montesquieu não seja a mesma que tenhamos hoje no Século XXI, tal como bem explica José Levi (2008, p. 62), a função de separá-los continua a ter sua justificação central assentada na preocupação liberal de evitar abusos contra os direitos dos cidadãos e, mediante os mecanismos de freios e contrapesos concebidos nas faculdades de exercício entre os poderes, evitar a "degeneração institucional."

Nunca se cogitou, portanto, num arranjo que possibilitasse o rejulgamento amplo do judiciário no exercício revisional das decisões proferidas pelo Cade, mas na preocupação central de evitar abusos.

\section{REFERÊNCIAS:}

AMARAL JÚNIOR, José Levi Mello do. Sobre a organização de poderes em Montesquieu: comentários ao Capítulo VI do Livro XI de O Espírito das Leis. Revista dos Tribunais. São Paulo, v. 868, p. 53-68, 2008.

ARAGÃO, Alexandre Santos de. Agências reguladoras e a evolução do direito administrativo econômico. Rio de Janeiro: Forense, 2005.

BERLIN, Isaiah. Estudos sobre a humanidade: uma antologia de ensaios. São Paulo: Companhia das letras, 2002.

BOURDIEU, Pierre. 0 poder simbólico. 14. ed. Rio de Janeiro: Bertrand Brasil, 2010.

BRASIL. Conselho Administrativo de Defesa Econômica. Processo Administrativo no

0800.024581/1994-77. Disponivel em: www.cade.gov.br Acesso em: 08 jan. 2021.

Inquérito Administrativo no 08012.008859/2009-86. Disponível em: www. 
cade.gov.br. Acesso em: 08 jan. 2021.

Processo Administrativo no 08700.004602/2016-26. Requerimento de Termo de Compromisso de Cessação (TCC) da rede CASCOL. Disponível em: www.cade.gov.br. Acesso em: 08 jan. 2021.

Cade em números. Disponível em: www.cade.gov.br. Acesso em: 08 jan. 2021.

BRASIL. Conselho da Justiça Federal. Seminário “Os Desafios da Judicialização, da Defesa da Concorrência, da Regulação e do Comércio Internacional - 2015. Brasília: CJF, Série Cadernos do CEJ, v. 32. Disponivel em: https://www.cjf.jus.br/cjf/corregedoria-da-justica-federal/centro-de-estudos-judiciarios-1/eventos/eventos-cej/2015/os-desafios-da\%20judicializacao-da-defesa-da-concorrencia Acesso em 10 mar. 2021.

BRASIL. Supremo Tribunal Federal (1. Turma). Agravo Regimental no Recurso Extraordinário no 1.083.955/DF. Relator: Min. Luiz Fux, 28 de maio de 2019. Diário da Justiça Eletrônico. Disponível em: www.stf.jus.br. Acesso em: 08 jan. 2021.

BUSTAMANTE, Thomas da Rosa. Teoria do Direito e Decisão Racional. São Paulo: Saraiva, 2008.

CARVALHO. Vinicius Marques de. A Política de Defesa da Concorrência Quatro Anos Depois: Ainda em Busca de Melhores Práticas? In: CARVALHO, Vinicius Marques de (coord.). A Lei 12.529/2011 e a Nova Política de Defesa da Concorrência. São Paulo: Singular, 2015.

COELHO, Tulio Freitas do Egito. Judicialização sob a perspectiva da advocacia concorrencia. In: CARVALHO. Vinicius Marques de (org.). A Lei 12.529/2011 e a Nova Política de Defesa da Concorrência. São Paulo: Singular, 2015.

COUTINHO, Diogo. Direito e institucionalismo econômico: apontamentos sobre uma fértil agenda de pesquisa. Revista de Economia Política, São Paulo, v. 37, n. 3 (148), jul./set. p. 565-586, 2017.

DRAGO, Bruno de Luca. Responsabilidade especial dos agentes econômicos dominantes. Tese (Doutorado em Direito) - Faculdade de Direito, Universidade de São Paulo, São Paulo, 2015.

FORGIONI, Paula A. Os fundamentos do antitruste. 2. ed. São Paulo: Revista dos Tribunais, 2005.

FERRAZ JUNIOR, Tércio Sampaio. A ciência do direito. 3. ed. São Paulo: Atlas, 2014.

FREITAS FILHO, Roberto. Intervenção judicial nos contratos e aplicação dos princípios e das cláusulas gerais: o caso do leasing. Porto Alegre: Sergio Antonio Fabris, 2009.

HESSE, Konrad. Escritos de Derecho Constitucional. Madrid: Centro de Estudios Constitucionales, 1983.

KELSEN, Hans. Jurisdição constitucional. São Paulo: Martins Fontes, 2003.

KELSEN, Hans. Teoria pura do Direito. 6. ed. São Paulo: Revista dos Tribunais, 2009.

KOOP, Christel; LODGE, Martin. What is regulation? An interdisciplinary concept analysis in Regulation and Governance. New Jersey: Wiley Publishing, 2015.

MONTESQUIEU. De l'esprit des lois (1758). Versão eletrônica de 2015 disponivel em: http:/ / www. uqac.uquebec.ca/zone30. Acesso em 10 de fevereiro de 2021. 
OST, FRANÇOIS. Júpiter, Hércules, Hermes: tres modelos de juez. Revista sobre enseñanza del derecho. Buenos Aires, número 8, Ano 4, 2007, p. 101-130.

MARQUES NETO, Floriano Azevedo. A nova regulação estatal e as agências independentes. In: SUNDFELD, Carlos Ari (coord.). Direito administrativo econômico. São Paulo: Malheiros, 2002.

PISTOR, Katharina. The code of capital: how the law creates wealth and inequality. U.S.: Princeton, 2020.

SCHAUER, Frederick. Thinking like a lawyer: a new introduction to legal reasoning. U.S.: Harvard University Press, 2009.

WEBER, Max. Economia e sociedade - Tomo I. Brasília: Unb, 2009. 